\title{
PENGARUH PEMBERIAN JUS PARE (Momordica charantia Linn.) dan JUS JERUK NIPIS (Citrus aurantifolia) TERHADAP PENINGKATAN KADAR KOLESTEROL HDL (High Density Lipoprotein) TIKUS SPRAGUE DAWLEY DISLIPIDEMIA
}

\author{
Muthia Nada Syadza, Muflihah Isnawati* \\ Program Studi Ilmu Gizi Fakultas Kedokteran Universitas Diponegoro \\ J1.Dr.Sutomo No.18, Semarang, Telp (024) 8453708, Email : gizifk@ undip.ac.id
}

\begin{abstract}
Background : Bitter melon (Momordica charantia Linn.) and lime (Citrus aurantifolia) has been known as a potential agent to decrease risk of cardiovascular disease (CVD) by increasing HDL cholesterol (HDL-C) level. However, the study of potential effect of bitter melon and lime juice still has controversy. This study aimed to investigate the effect of bitter melon juice and lime juice administration to HDL-C of dyslipidemic Sprague Dawley rats.

Methods: This is an true experimental study with randomized control group on 28 male Sprague Dawley rats. Rats were divided into 4 group with 7 rats each group. For 14 days were induced to be dyslipidemia, then for 14 days administered treatment bitter melon juice, lime juice and combination of bitter melon juice and lime juice. The distribution were comfeed BR2 and clean water ad libitium (Control), $2 \mathrm{ml}$ bitter melon juice (P1), $2 \mathrm{ml}$ lime juice (P2), $4 \mathrm{ml}$ combination of bitter melon juice and lime juice (P3). The level of HDL-C examined enzymatically with CHOD-PAP method. The result will be tested using paired t-test and One Way ANOVA.

Result: The study showed that P1's HDL-C increased 117,3\% ( $p=0,001), P 2$ 's HDL-C increased 116,4\% (p=0,000) and P3's HDL increased $144 \%$. ( $p=0,000)$.

Conclution : There was no different effect of administration of bitter melon juice, lime juice and combination of bitter melon and lime juice to increase HDL-C.
\end{abstract}

Keyword: bitter melon juice; lime juice; HDL; dyslipidemic

\begin{abstract}
ABSTRAK
Latar Belakang : Buah pare (Momordica charantia Linn.) dan jeruk nipis (Citrus aurantifolia) diketahui memiliki potensi menurunkan risiko penyakit dislipidemia dengan meningkatkan kadar kolesterol HDL. Namun penelitian sebelumnya mengenai efek peningkatan kadar koletserol HDL masih terdapat kontroversi. Penelitian ini bertujuan mengetahui pengaruh pemberian jus pare dan jus jeruk nipis terhadap peningkatan kadar kolesterol HDL tikus dislipidemia.
\end{abstract}

Metode : Penelitian true experimental dengan randomized control group ini dilakukan pada 28 tikus jantan galur Sprague Dawley dislipidemia. Tikus dibagi menjadi 4 kelompok dengan 7 ekor tiap kelompok. Tikus diinduksi dislipidemia selama 14 hari, kemudian diberi perlakuan jus pare, jus jeruk nipis dan kombinasi jus pare dan jus jeruk nipis. Pemberian selama 14 hari melalui sonde dengan pembagian pakan standar dan minum ad libitium (kontrol), jus pare $2 \mathrm{ml}(P 1)$, jus jeruk nipis $2 \mathrm{ml}(P 2)$, dan kombinasi jus pare dan jus jeruk nipis (P3). Pemeriksaan kadar HDL diperiksa secara enzimatis dengan metode CHOD-PAP. Hasil pengukuran diuji dengan paired t-test dan One Way ANOVA.

Hasil : Kelompok P1 menunjukkan peningkatan kadar kolesterol HDL 117,3\% (p=0,001), kelompok P2 mengalami peningkatan kadar kolesterol HDL 116,4\% (p=0,000), dan kelompok P3 mengalami peningkatan kolesterol HDL $144 \%(p=0,000)$.

Simpulan : Tidak ada perbedaan pengaruh pemberian jus pare, jus jeruk nipis \& kombinasi jus pare dan jus jeruk nipis terhadap peningkatan kolesterol HDL.

Kata Kunci : jus pare; jus jeruk nipis; HDL; dislipidemia

\section{PENDAHULUAN}

Penyakit jantung koroner adalah gangguan fungsi jantung akibat otot jantung kekurangan darah karena adanya penyempitan pembuluh darah koroner. Dislipidemia merupakan faktor risiko utama dari penyakit kardiovaskuler. Dislipidemia ditandai dengan hipertrigliseridemia, penurunan kadar kolesterol HDL, dan kenaikan konsentrasi kolesterol LDL. ${ }^{1}$ HDL (High Density Lipoprotein) berasal dari bagian produk yang dihasilkan dalam katabolisme trigliserida, komponen lainnya dibuat di hati dan usus. $^{2}$ Prevalensi dislipidemia berdasarkan Riskesdas 2013, memperlihatkan proporsi penduduk $\geq 15$ tahun dengan kadar HDL dibawah nilai normal menurut NCEP-ATP III secara keseluruhan didapatkan 22,9\% penduduk Indonesia memiliki kadar kolesterol HDL dibawah nilai normal, dengan proporsi laki-laki didapatkan dua kali lipat lebih (34,8\%) dibandingkan perempuan $(15,3 \%){ }^{3}$

The International Atherosclerosis Society (IAS) merekomendasikan melakukan terapi pada

\footnotetext{
${ }^{*}$ Penulis Penanggungjawab
} 
dislipidemia untuk menurunkan risiko atherosclerotic cardiovascular disease (ASCVD) ${ }^{4}$. Bukti epidemiologi menunjukkan bahwa rendahnya kadar kolesterol HDL merupakan target potensial terapi pada dislipidemia. ${ }^{5}$ Prevalensi rendahnya kolesterol HDL secara bermakna dikaitkan dengan asupan buah dan sayuran yang tidak adekuat. ${ }^{6,7}$ Salah satu buah atau sayuran yang dapat memberikan efek antilipidemik adalah pare (Momordica charantia L).

Pare (Momordica charantia L.) adalah tanaman mengandung vitamin B \& C, flavonoid, polifenol, saponin dan senyawa antioksidan yang bermanfaat sebagai antilipidemik. ${ }^{8,9,10,11,22}$ Mekanisme peningkatan kadar kolesterol HDL dikarenakan adanya efek hipokolesterolemik yang meningkatkan pengeluaran Apolipoprotein A-I (Apo A-1), dimana Apo A-1 merupakan protein utama penyusun HDL. ${ }^{12}$ Pada sebuah penelitian menggunakan tikus mencit usia 10 bulan yang diberi jus pare dengan dosis $0,5 \mathrm{ml}, 1 \mathrm{ml}$ dan $1,5 \mathrm{ml}$ selama 10 hari mampu meningkatkan kadar kolesterol HDL secara signifikan berturut-turut $49,44 \pm 16,44, \quad 67,96 \pm 19,20$ dan $83,88 \pm 10,50 .{ }^{14}$ Namun, penelitian lainnya pada tikus wistar usia 7 minggu hiperkolesterolemia yang diberi ekstrak pare $1 \mathrm{~g}$ /hari selama 4 minggu justru menunjukkan penurunan kadar kolesterol HDL. ${ }^{15}$ Belum banyak penelitian mengenai kombinasi pare dengan tanaman lain yang mempunyai potensi antilipidemik, salah satunya yaitu buah jeruk.

Jeruk nipis (Citrus aurantifolia) adalah buah yang mengandung vitamin $\mathrm{C}$ dan zat flavonoid utama berupa hesperidin. Kandungan hesperidin jeruk nipis lebih besar dibandingkan jeruk lainnya yaitu $15,64 \mathrm{mg} / 100 \mathrm{~g} .{ }^{49}$ Penelitian sebelumnya telah menunjukkan bahwa flavonoid dari buah jeruk, berupa hesperidin dapat meningkatkan kadar kolesterol HDL pada subjek manusia hiperkolesterolemia. ${ }^{16,17}$ Penelitian terbaru dengan dosis $480 \mathrm{ml} /$ hari selama 12 bulan menunjukkan hanya $8 \%$ dari total subjek yang mengalami peningkatan kolesterol HDL, terdapat pengaruh terhadap peningkatan kadar kolesterol HDL tetapi tidak bermakna. ${ }^{18}$ Penelitian lain dengan menggunakan tikus wistar hiperkolesterolemia yang diberi dua jenis jeruk (jeruk lemon dan jeruk nipis) dengan dosis $1 \mathrm{ml} /$ hari selama 7 hari menunjukkan penurunan kadar kolesterol yang signifikan pada kedua jenis jeruk, namun penurunan yang lebih besar terjadi pada jeruk nipis daripada jeruk lemon. ${ }^{19}$

Subjek dalam penelitian ini adalah tikus jantan galur Sprague Dawley. Galur ini dipilih karena memiliki respon yang baik dalam penelitian yang menggunakan kolesterol sebagai indikator dan penggunaan tikus jantan karena dapat memberikan hasil penelitian yang lebih stabil karena tidak dipengaruhi hormon estrogen. ${ }^{13}$ Dalam penelitian ini, digunakan penambahan jeruk pada jus pare, dikarenakan jeruk mempunyai rasa yang $\mathrm{khas}^{20}$ dan adanya potensi antilipidemik pada buah jeruk ${ }^{21,22}$, sehingga diharapkan dapat mengurangi rasa pahit pare dan menambah efek peningkatan kadar kolesterol HDL. Buah pare dan jeruk merupakan sumber antioksidan yang mudah didapat dan harganya terjangkau. ${ }^{23}$ Berdasarkan potensi yang terdapat dalam pare dan jeruk nipis dalam peningkatan kadar kolesterol HDL, maka penelitian ini bertujuan mengetahui pengaruh pemberian jus pare dan jus jeruk nipis terhadap peningkatan kadar kolesterol HDL tikus dislipidemia.

\section{METODE PENELITIAN}

Penelitian ini merupakan eksperimental laboratorik sesungguhnya (true experimental) jenis pre-post test randomized control group design yang dilakukan di Laboratorium Fisiologi Hewan Jurusan Biologi Fakultas MIPA Universitas Negeri Semarang (UNNES) dengan variabel bebas dalam penelitian ini yaitu pemberian jus pare, jus jeruk nipis, kombinasi jus pare dan jeruk nipis, serta variabel tergantung adalah kadar kolesterol HDL.

Sampel tikus yang digunakan yaitu tikus jantan Sprague dawley sebanyak 28 ekor berdasarkan rumus Federer, yang diperoleh dari Bagian Farmakologi dan Farmasi Klinik, Fakultas Farmasi, Universitas Gadjah Mada, Yogyakarta. Kriteria inklusi penelitian ini adalah tikus jantan galur Sprague dawley usia 6-8 minggu dengan berat badan 100-150, sedangkan kriteria eksklusinya adalah tikus mengalami perubahan perilaku (menolak makan dan lemas), terjadi penurunan berat badan $10 \%$ per minggu, dan tikus mati ketika penelitian. Sampel mengalami tahap aklimatisasi selama 14 hari dengan pemberian pakan standar $B R$ 2 sebanyak 20 g/ekor/hari serta minum air ad libitum. Pakan standar mengandung air 12\%, protein $19-21 \%$, lemak $4-8 \%$, serat kasar $5 \%$, abu $8 \%$, kalsium $0,9-1,2 \%$, fosfor $0,7-1 \%$,. Tikus ditempatkan pada kandang individu, sisa asupan pakan dipantau setiap hari dan berat badan dipantau setiap minggu, serta selama penelitian tidak ada sampel yang mengalami drop out. Pada hari ke 16 dilakukan tahap induksi dislipidemia selama 14 hari, seluruh sampel diberikan otak sapi sebanyak 2 $\mathrm{ml} / \mathrm{ekor} / \mathrm{hari}$ dengan cara sonde (kandungan dalam 100 gram otak sapi adalah $3100 \mathrm{mg}$ kolesterol dan $2 \mathrm{~g}$ asam lemak jenuh). ${ }^{40}$ Setelah induksi dislipidemia, pada hari ke 31 seluruh sampel dibagi 
secara simple random sampling menjadi 4 kelompok yaitu kelompok kontrol (K), perlakuan 1 (P1), perlakuan 2 (P2), dan perlakuan 3 (P3). Selama 14 hari pada kelompok P1 diberi jus pare 2 $\mathrm{ml} / \mathrm{ekor} / \mathrm{hari}$, P2 diberi jus jeruk nipis 2 ml/ekor/hari, dan P3 diberi kombinasi jus pare dan jus jeruk nipis $4 \mathrm{ml} /$ ekor/hari, sedangkan kelompok kontrol hanya diberikan pakan standar dan minum ad libitium.

Selama penelitian dilakukan pengambilan darah sampel sebanyak 3 kali untuk memeriksa kadar kolesterol HDL pada serum sampel. Pengambilan darah I dilakukan setelah tahap aklimatisasi yaitu pada hari ke-15 untuk mengetahui kadar kolesterol HDL awal tikus coba, pengambilan darah II dilakukan setelah tahap induksi dislipidemia yaitu pada hari ke-30 untuk memastikan kadar kolesterol HDL memenuhi kondisi dislipidemia dan pengambilan darah III dilakukan setelah tahap intervensi yaitu pada hari ke-46. Darah tikus diambil melalui pleksus retroorbitalis sebanyak $2 \mathrm{ml}$ setelah dipuasakan selama 12 jam. Sampel darah yang telah diambil diletakkan pada tabung dan dipisahkan antara darah dan serum melalui proses sentrifuge oleh peneliti. Serum darah kemudian digunakan untuk pemeriksaan kadar kolesterol HDL secara enzimatis dengan metode CHOD-PAP yang dilakukan di Balai Laboratorium Kesehatan Dinas Kesehatan Pemerintah Provinsi Jawa Tengah.

Pembuatan jus pare menggunakan daging buah pare jenis pare gajih atau pare bodas sebanyak $75 \mathrm{~g}$ yang telah dipisahkan dari bijinya, kemudian dimasukkan dalam juicer tanpa penambahan air sehingga diperoleh $\pm 40 \mathrm{ml}$ jus pare. Pembuatan jus jeruk nipis yaitu dengan memeras jeruk nipis sebanyak $90 \mathrm{~g}$ dengan alat perasan jeruk, sehingga diperoleh air beserta bulirnya sebanyak $\pm 60 \mathrm{ml}$. Kombinasi jus pare dan jeruk terdiri dari jus pare dan jus jeruk nipis yang telah dicampur dengan perbandingan 1:1. Pemberian jus pada tikus coba dilakukan dengan penyondean. Pembuatan jus dilakukan setiap hari dan bila ada sisa jus maka dibuang.

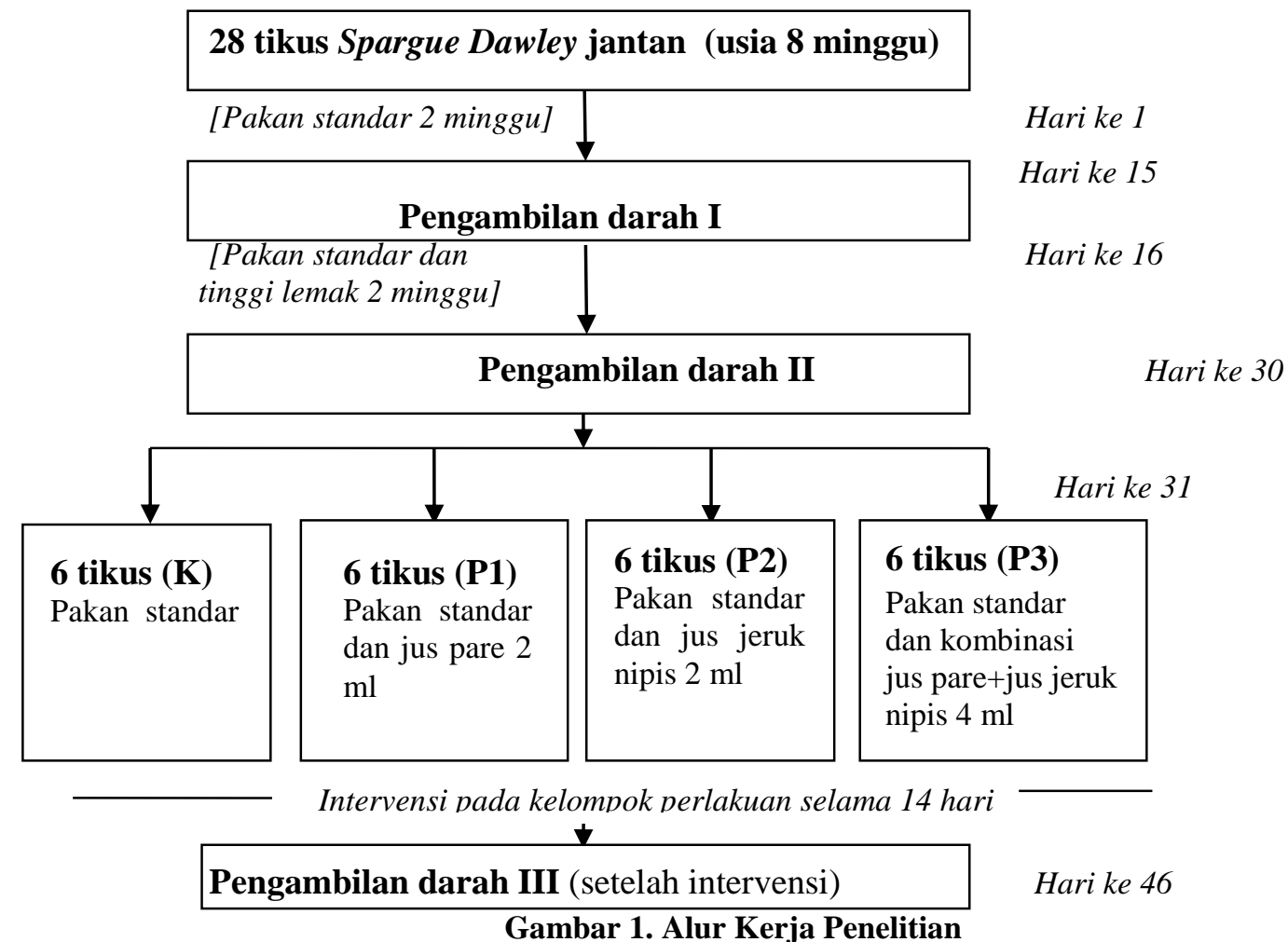

Pemberian dosis jus jeruk nipis didasarkan pada penelitian sebelumnya pada kelinci sebesar 5 $\mathrm{ml}$ dengan kandungan hesperidin sebesar 0,195 mg kemudian dikonversikan ke dosis tikus. ${ }^{19,26}$ Pemberian dosis jus pare segar (fresh juice) didasarkan pada dosis anjuran untuk manusia yaitu sebesar $50-100 \mathrm{ml} .{ }^{14}$ Dosis yang digunakan adalah $100 \mathrm{ml}$ sebagai dosis optimal. Kemudian dosis tersebut dikonversi ke dosis tikus, sehingga didapatkan dosis jus pare $2 \mathrm{ml}$; jus jeruk $2 \mathrm{ml}$ serta dosis kombinasi jus pare dan jus jeruk $4 \mathrm{ml}$.

Data kadar kolesterol HDL diuji normalitasnya dengan uji Shapiro Wilk. Tahap sebelum dan setelah intervensi juga dilakukan uji beda paired t-test serta untuk mengetahui perbedaan 
pengaruh dari keempat kelompok perlakuan dilakukan uji statistik parametrik one way ANOVA.
HASIL PENELITIAN

Perubahan Asupan Pakan dan Berat Badan Tikus Selama Penelitian Asupan Pakan

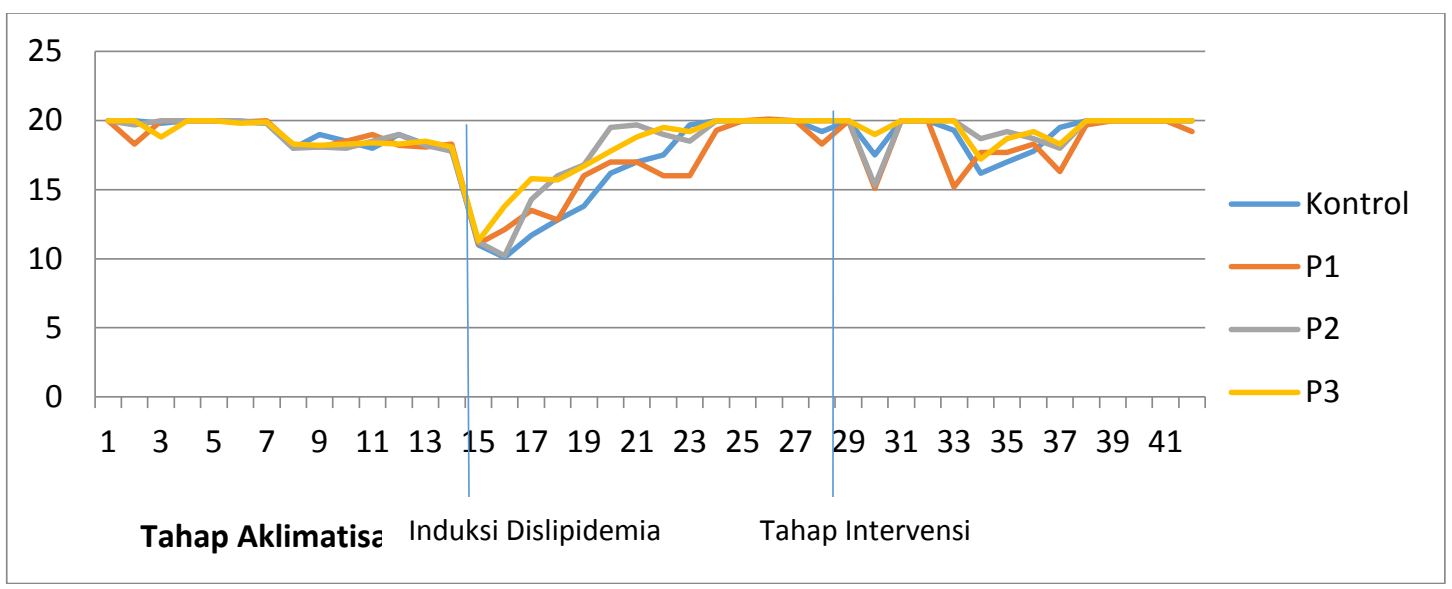

Gambar 2. Perubahan Asupan Pakan Tikus

Gambar 2 menunjukkan asupan pakan tikus pada tahap induksi dislipidemia mengalami penurunan dibandingkan tahap aklimatisasi dan mengalami peningkatan selama tahap intervensi.

Tabel 1. Rerata Asupan Pakan Standar Sebelum dan Setelah Pemberian Intervensi

\begin{tabular}{lcccccc}
\hline Kelompok & N & \multicolumn{2}{c}{ Asupan Pakan Standar (g) } \\
\cline { 2 - 7 } & \multicolumn{7}{c}{$\begin{array}{c}\text { Rerata } \pm \text { SD } \\
\text { Sebelum }\end{array}$} & $\begin{array}{c}\text { Rerata } \pm \text { SD } \\
\text { Setelah }\end{array}$ & $\Delta(\mathbf{g})$ & $\Delta(\%)$ & $\boldsymbol{P}$ \\
\hline K & 6 & $16,2 \pm 1,27$ & $18,4 \pm 1,21$ & 2,2 & 13,7 & $0,020^{\mathrm{a}^{*}}$ \\
P1 (Pare) & 6 & $16,1 \pm 2,17$ & $18,0 \pm 0,92$ & 1,9 & 11,4 & $0,083^{\mathrm{a}}$ \\
P2 (Jeruk) & 6 & $17,5 \pm 0,56$ & $18,9 \pm 0,39$ & 1,4 & 8,3 & $0,001^{\mathrm{a}^{*}}$ \\
P3 (Pare+Jeruk) & 6 & $17,7 \pm 1,64$ & $19,5 \pm 0,53$ & 1,8 & 10,1 & $0,019^{\mathrm{b}^{*}}$ \\
\hline \multicolumn{7}{c}{ Anova $\Delta \boldsymbol{P}$} \\
\hline
\end{tabular}

a paired t-test $*$ berbeda bermakna

Rerata asupan pakan standar setelah pemberian intervensi mengalami peningkatan. Peningkatan asupan pakan standar tikus tertinggi dijumpai pada kelompok kontrol sebesar 2,2 g. Hasil analisis secara statistik menunjukkan rerata asupan pakan standar sebelum dan setelah intervensi kelompok kontrol, jus jeruk nipis dan kombinasi jus pare \& jus jeruk nipis mengalami peningkatan yang bermakna dengan $p<0,05$. Hasil analisis perubahan $(\Delta)$ asupan pakan menunjukkan tidak ada perbedaan antar kelompok perlakuan dan kontrol dengan $p>0,05$. Hasil analisis statistik perubahan asupan pakan antara kelompok kontrol dengan masing-masing kelompok perlakuan menunjukkan tidak ada perbedaan yang signifikan $(p>0,05)$.

\section{Berat Badan}

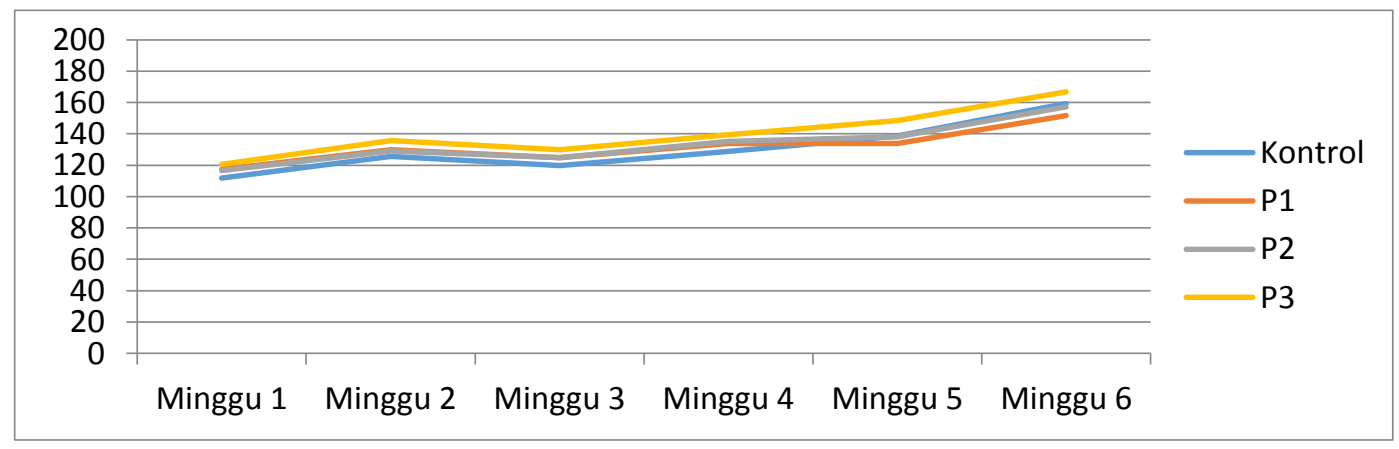

Gambar 3. Perubahan Berat Badan Tikus 
Gambar 2 menunjukkan berat badan tikus pada minggu pertama (aklimatisasi) mengalami kenaikan, sedangkan minggu ketiga (tahap induksi dislipidemia) mengalami penurunan tetapi mulai minggu keempat hingga keenam (tahap intervensi) mengalami peningkatan dan cenderung stabil.

Tabel 2. Rerata Berat Badan Standar Sebelum dan Setelah Pemberian Intervensi

\begin{tabular}{|c|c|c|c|c|c|c|}
\hline \multirow[t]{2}{*}{ Kelompok } & \multirow[t]{2}{*}{$\mathbf{N}$} & \multicolumn{5}{|c|}{ Berat Badan (g) } \\
\hline & & $\begin{array}{c}\text { Rerata } \pm \text { SD } \\
\text { Sebelum }\end{array}$ & $\begin{array}{c}\text { Rerata } \pm \text { SD } \\
\text { Setelah }\end{array}$ & $\Delta(\mathrm{g})$ & $\Delta(\%)$ & $P$ \\
\hline $\mathbf{K}$ & 6 & $128,8 \pm 11,30$ & $159,5 \pm 16,39$ & 30,7 & 23,8 & $0,001^{\mathrm{a}^{*}}$ \\
\hline P1 (Pare) & 6 & $134,0 \pm 13,45$ & $151,7 \pm 13,30$ & 17,7 & 13,2 & $0,022^{\mathrm{a}^{*}}$ \\
\hline P2 (Jeruk) & 6 & $139,7 \pm 7,60$ & $157,3 \pm 14,50$ & 17,6 & 12,6 & $0,061^{\mathrm{a}}$ \\
\hline P3 (Pare+Jeruk) & 6 & $139,5 \pm 13,32$ & $166,7 \pm 16,7$ & 27,2 & 19,5 & $0,003^{\mathrm{a}^{*}}$ \\
\hline \multicolumn{3}{|c|}{ Anova $\triangle P$} & & & & 0,274 \\
\hline
\end{tabular}

${ }^{a}$ paired $t$-test $*$ berbeda bermakna

Rerata berat badan tikus setelah pemberian intervensi mengalami peningkatan. Peningkatan berat badan tikus tertinggi dijumpai pada kelompok kontrol sebesar 30,7 g. Hasil analisis secara statistik menunjukkan rerata berat badan tikus sebelum dan setelah intervensi kelompok kontrol, jus pare dan kombinasi jus pare dan jus jeruk nipis mengalami peningkatan yang bermakna $(p<0,05)$. Hasil analisis perubahan $(\Delta)$ berat badan tikus menunjukkan tidak ada perbedaan antara kelompok perlakuan dan kontrol $(p>0,05)$. Hasil analisis statistik perubahan berat badan antara kelompok kontrol dengan masing-masing kelompok perlakuan menunjukkan tidak ada perbedaan yang signifikan $(p>0,05)$.

\section{Kadar Kolesterol HDL Sebelum dan Setelah Induksi Dislipidemia}

Tabel 3. Rerata Kadar Kolesterol HDL Sebelum dan Setelah Induksi Dislipidemia

\begin{tabular}{llcl}
\hline Kelompok & N & \multicolumn{2}{c}{ Kolesterol HDL $(\mathbf{m g} / \mathbf{d L})$} \\
\cline { 2 - 4 } & & $\begin{array}{c}\text { Rerata } \pm \text { SD } \\
\text { Sebelum }\end{array}$ & $\begin{array}{l}\text { Rerata } \pm \text { SD } \\
\text { Setelah }\end{array}$ \\
\hline K & 6 & $64,7 \pm 17,43$ & $33,4 \pm 3,66$ \\
P1 (Pare) & 6 & $56,2 \pm 6,34$ & $29,4 \pm 7,58$ \\
P2 (Jeruk) & 6 & $53,6 \pm 7,34$ & $30,6 \pm 6,53$ \\
P3 (Pare+Jeruk) & 6 & $57,2 \pm 7,85$ & $27,8 \pm 6,86$ \\
\hline
\end{tabular}

Hasil rerata kadar kolesterol HDL semua kelompok setelah pemberian induksi dislipidemia selama 14 hari mengalami penurunan. Rerata kadar kolesterol HDL setelah pemberian induksi dislipidemia telah mencapai kondisi dislipidemia yaitu $<40 \mathrm{mg} / \mathrm{dL}^{24}$. Hasil analisis secara statistik menunjukkan tidak ada perbedaan kadar kolesterol
HDL pada tahap setelah induksi dislipidemia antar kelompok perlakuan dan kontrol dengan $\mathrm{p}=0,485$ $(p>0,05)$ sehingga data tersebut dapat dianggap homogen.

Kadar Kolesterol HDL Sebelum dan Setelah Pemberian Jus Pare, Jus Jeruk Nipis dan Kombinasi Jus Pare dan Jus Jeruk Nipis

Tabel 4. Rerata Kadar Kolesterol HDL Sebelum dan Setelah Pemberian Intervensi

\begin{tabular}{lllllll}
\hline Kelompok & $\mathbf{N}$ & \multicolumn{2}{c}{ Kolesterol HDL $(\mathbf{m g} / \mathbf{d L})$} \\
\cline { 2 - 7 } & \multicolumn{2}{c}{$\begin{array}{l}\text { Rerata } \pm \text { SD } \\
\text { Sebelum }\end{array}$} & $\begin{array}{c}\text { Rerata } \pm \text { SD } \\
\text { Setelah }\end{array}$ & $\begin{array}{l}\Delta \\
(\mathbf{m g} / \mathbf{d L})\end{array}$ & $\Delta(\%)$ & $\boldsymbol{P}$ \\
\hline K & 6 & $33,4 \pm 3,66$ & $70,8 \pm 16,14$ & 37,4 & 111,9 & $0,001^{\mathrm{a}^{*}}$ \\
P1 (Pare) & 6 & $29,4 \pm 7,58$ & $63,9 \pm 8,86$ & 34,5 & 117,3 & $0,001^{\mathrm{a}^{*}}$ \\
P2 (Jeruk) & 6 & $30,6 \pm 6,53$ & $66,2 \pm 8,09$ & 35,6 & 116,4 & $0,000^{\mathrm{a}^{*}}$ \\
P3 (Pare+Jeruk) & 6 & $27,8 \pm 6,86$ & $67,8 \pm 5,29$ & 40,0 & 144,0 & $0,000^{\mathrm{a}^{*}}$ \\
\hline \multicolumn{7}{c}{ Anova $\Delta \boldsymbol{P}$} \\
paired $t$-test *berbeda bermakna
\end{tabular}

Tabel 4 menunjukkan bahwa rerata kadar kolesterol HDL pada semua kelompok setelah pemberian intervensi mengalami peningkatan dibandingkan sebelum pemberian intervensi. Bila 
dilihat dari hasil persen perubahan kadar kolesterol HDL, ketiga kelompok perlakuan mengalami persen peningkatan yang lebih besar daripada kelompok kontrol. Peningkatan kadar kolesterol HDL tikus dari tertinggi hingga terendah yaitu kelompok pemberian kombinasi jus pare \& jus jeruk nipis $(144 \%)$, jus pare $(117,3 \%)$, jus jeruk nipis $(116,4 \%)$ dan kontrol $(111,9 \%)$.

Hasil analisis secara statistik menunjukkan rerata kadar kolesterol HDL tikus sebelum dan setelah intervensi pada semua kelompok mengalami peningkatan yang bermakna $(p<0,05)$. Namun secara statistik kadar kolesterol HDL antara kelompok kontrol dan semua kelompok perlakuan menunjukkan tidak ada perbedaan peningkatan, dengan $p=0,857(p>0,05)$. Analisis secara statistik terhadap perubahan kadar kolesterol HDL antara kelompok kontrol dengan masing-masing kelompok perlakuan menunjukkan tidak ada perbedaan yang signifikan $(p>0,05)$. Hasilnya yaitu kontrol dengan perlakuan $1 \quad(p=0,757)$, kontrol dengan perlakuan $2(p=0,733)$, dan kontrol dengan perlakuan $3(p=0,476)$.

\section{PEMBAHASAN}

\section{Perubahan Asupan Pakan dan Berat Badan Tikus}

Pada tahap induksi dislipidemia, rerata asupan pakan tikus semua kelompok mengalami penurunan. Penurunan ini kemungkinan dikarenakan pakan tinggi lemak dapat memperlambat waktu pengosongan lambung sehingga tikus mengasup pakan standar lebih sedikit bila dibandingkan pada tahap aklimatisasi yang hanya diberikan pakan standar saja. Namun, selama tahap intervensi rerata asupan pakan semua kelompok mengalami peningkatan. Peningkatan asupan ini dimungkinkan karena pakan intervensi yang diberikan lebih cepat diabsorbsi dibandingkan pakan tinggi lemak, sehingga pakan standar yang diasup lebih banyak daripada tahap pemberian induksi dislipidemia. Hasil ini sesuai dengan sebuah penelitian yang menjelaskan bahwa asupan pakan standar pada saat pemberian diet tinggi lemak yaitu $80,6 \pm 13,28 \mathrm{kkal} / \mathrm{hari}$, sedangkan saat pemberian pakan standar saja yaitu $90,69 \pm 12,47 \mathrm{kkal} / \mathrm{hari} .{ }^{47}$ Perubahan berat badan tikus selama penelitian yaitu pada tahap induksi dislipidemia semua kelompok mengalami penurunan berat badan, tetapi selama tahap intervensi mengalami peningkatan berat badan dan cenderung stabil. Penurunan berat badan tersebut mungkin dapat disebabkan oleh stres. Stres pada tikus dapat disebabkan oleh cara pemegangan, pengambilan darah, dan proses penyondean. ${ }^{33}$ Penurunan berat badan sejalan dengan peningkatan kadar hormon kortikosteron yang merombak cadangan glukosa dan lemak untuk penyediaan sumber energi metabolisme yang digunakan dalam merespon stres sehingga terjadilah penurunan berat badan pada tikus.

Peningkatan asupan pakan standar dan berat badan tertinggi dijumpai pada kelompok kontrol sebesar 2,2 g dan 30,7 g. Berdasarkan hasil tersebut dapat dilihat bahwa kelompok kontrol mengalami peningkatan asupan pakan yang tinggi dan juga diikuti tingginya peningkatan berat badan. Hal ini dikarenakan besarnya asupan makan berpengaruh terhadap besarnya asupan energi yang kemudian disimpan sebagai lemak dan akhirnya berimplikasi terhadap penambahan berat badan dari hewan coba. ${ }^{2}$

\section{Kadar Kolesterol HDL Sebelum dan Setelah Induksi Dislipidemia}

Selama pemberian pakan tinggi kolesterol, kadar kolesterol HDL tikus mengalami penurunan hingga berada dalam kondisi dislipidemia. Hal ini sesuai dengan penelitian dengan pemberian diit tinggi kolesterol dapat menurunkan kolesterol HDL secara signifikan. ${ }^{30}$ Penurunan kadar kolesterol HDL dapat disebabkan oleh banyaknya asam lemak jenuh di dalam pakan kolesterol yang menyebabkan terjadinya penekanan sintesis kolesterol HDL melalui penurunan kadar apolipoprotein A-1 yang merupakan prekursor dari pembentukan HDL. ${ }^{28}$

\section{Kadar Kolesterol HDL Sebelum dan Setelah Pemberian Jus Pare (Momordica charantia L.) dan Jus Jeruk Nipis (Citrus aurantifolia).}

Pada penelitian ini, secara keseluruhan menunjukkan tidak ada perbedaan peningkatan kadar kolesterol HDL antara kelompok kontrol dan semua kelompok perlakuan $(p>0,05)$. Hasil ini tidak sejalan dengan penelitian sebelumnya yaitu penelitian menggunakan tikus mencit usia 10 bulan yang diberi jus pare dengan dosis $0,5 \mathrm{ml}, 1 \mathrm{ml}$ dan $1,5 \mathrm{ml}$ selama 10 hari mampu meningkatkan kadar kolesterol HDL secara signifikan berturut-turut $49,44 \pm 16,44, \quad 67,96 \pm 19,20$ dan $83,88 \pm 10,50 .{ }^{14}$ Sedangkan penelitian lain pada tikus wistar jantan usia 20 minggu yang diberi perasan pare $1,5 \mathrm{ml}$ selama 3 minggu menunjukkan peningkatan HDL yang signifikan yaitu sebesar $100,14 \pm 3,51$. Dan penelitian di Iran dengan menggunakan kelinci jantan hiperkolesterolemik yang diberi jus jeruk nipis sebanyak $5 \mathrm{ml}$ (setara dengan $2 \mathrm{ml}$ pada tikus) selama 60 hari menunjukkan peningkatan HDL secara signifikan yaitu sebesar $114,4 \pm 28,8 .^{26}$ Perbedaan hasil yang tidak sejalan dapat disebabkan oleh waktu pemberian yang berbeda, semakin lama 
masa intervensi dimungkinkan akan memberi efek yang optimal. Sampel yang digunakan juga berbeda sehingga masing-masing sampel mempunyai respon metabolisme tubuh yang berbeda terhadap perlakuan yang diberikan.

Faktor yang mungkin dapat menyebabkan tidak adanya perbedaan peningkatan kadar kolesterol HDL antar kelompok yaitu terbagi menjadi faktor yang dapat dikendalikan dan tidak dapat dikendalikan. Faktor yang dapat dikendalikan yaitu asupan, berat badan, aktifitas fisik, dan stres. Sedangkan faktor yang tidak dapat dikendalikan yaitu usia, jenis kelamin, dan hormon. Pada penelitian ini, peneliti sudah melakukan kontrol terhadap asupan pakan dan berat badan, tetapi asupan pakan dan berat badan masih dimungkinkan mempengaruhi kadar kolesterol HDL. Faktor usia, jenis kelamin dan galur tikus coba juga sudah dikontrol yaitu dengan menggunakan tikus jantan galur Sprague dawley usia 8 minggu.

Faktor yang belum dikontrol adalah aktifitas fisik, stres dan hormon. Faktor yang diduga berperan terhadap tidak adanya perbedaan kadar kolesterol HDL antara semua kelompok perlakuan dengan kelompok kontrol adalah stres, respon otomatis HDL menjalankan fungsinya dalam reverse cholesterol transport (RCT) dan perubahan diet.

Stres merupakan salah satu faktor yang dapat mempengaruhi kadar kolesterol $\mathrm{HDL}^{44}$. Pada penelitian ini, faktor yang dapat menyebabkan stres pada tikus yaitu proses penyondean ${ }^{33}$. Pada tahap intervensi, penyondean hanya dilakukan pada kelompok perlakuan, sedangkan kelompok kontrol tidak dilakukan proses sonde sehingga dapat mengurangi stres pada tikus yang dapat berpengaruh terhadap kadar kolesterol HDL. ${ }^{35}$ Stres ini dapat memicu impuls saraf ke hipotalamus dan hipofisis untuk meningkatkan sekresi hormon glukokortikoid dari korteks adrenal yang berperan dalam lipolisis. Stres juga dapat meningkatkan sekresi adrenalin, sedangkan adrenalin yang berlebihan dapat menyebabkan jejas pada pembuluh darah yang mengawali suatu patogenesis aterosklerosis. Adrenalin (epinephrine) disimpan dalam granul kromatin dan akan dilepas sebagai respon terhadap stres. Hormon epinephrine mempercepat pelepasan asam lemak bebas dari jaringan adiposa dan menaikkan kadar asam lemak bebas dari plasma dengan meningkatkan laju lipolisis pada simpanan triasilgliserol. Lipolisis akan meningkatkan kadar LDL dalam darah yang kaya akan Apolipoprotein B. Apolipoprotein B yang tinggi ini menghambat pembentukan Apolipoprotein A yang merupakan komponen utama untuk maturitas HDL. Hambatan pembentukan Apolipoprotein A menyebabkan kadar HDL dalam plasma mengalami penurunan sehingga stres dapat mengakibatkan penurunan kadar HDL. ${ }^{27,34}$

Selain faktor stres, dapat juga disebabkan oleh adanya respon otomatis HDL menjalankan fungsinya dalam reverse cholesterol transport (RCT) atau pengangkutan balik kolesterol, ${ }^{32}$ dimana HDL dapat meningkatkan efluks kelebihan kolesterol dari jaringan perifer dan mengembalikan ke hati untuk diekskresikan melalui empedu. ${ }^{45}$ Pada kondisi dislipidemia, membran sel jenuh terhadap kolesterol karena penerimaan LDL dan biosintesis internal yang berlebih. Untuk mengatasi hal ini, tubuh melakukan penyeimbangan kolesterol melalui pengambilan kolesterol dan membawanya ke cairan ekstraseluler untuk dibawa kembali ke hati. ${ }^{41,42,43}$

Faktor lain yang mungkin dapat menjadi penyebab tidak adanya perbedaan peningkatan kadar kolesterol HDL antar kelompok adalah perubahan diit yang dialami semua sampel. Adanya perubahan pemberian pakan tinggi lemak selama 14 hari dan setelah itu tidak diberikan pakan tinggi lemak kembali diduga dapat mempengaruhi kadar kolesterol HDL. Berdasarkan sebuah penelitian menjelaskan bahwa subjek manusia yang melakukan diit rendah lemak menunjukkan proporsi subjek yang mempunyai kadar kolesterol HDL < 40 $\mathrm{mg} / \mathrm{dL}$ lebih rendah dibandingkan subjek yang tidak melakukan diit rendah lemak. ${ }^{46}$

Selain faktor-faktor tersebut, mungkin dapat juga disebabkan oleh permasalahan teknis selama penelitian yang meliputi pengambilan darah tikus, proses sentrifuge darah menjadi bentuk serum, proses akomodasi pemeriksaan serum dan analisis serum.

Walaupun secara keseluruhan pemberian jus pare, jus jeruk nipis dan kombinasi jus pare \& jus jeruk nipis tidak memberikan perbedaan peningkatan kadar kolesterol HDL, tetapi peningkatan semua kelompok perlakuan lebih besar dibandingkan kelompok kontrol dan adanya perbedaan kadar kolesterol HDL sebelum dan setelah intervensi. Hal ini menunjukkan adanya potensi pada jus pare dan jus jeruk nipis untuk meningkatkan kadar kolesterol HDL. Peningkatan kadar kolesterol HDL tertinggi yaitu pada kelompok pemberian kombinasi jus pare dan jus jeruk nipis sebesar $144 \%$.

Peningkatan kadar kolesterol HDL pada kelompok dengan pemberian kombinasi jus pare dan jus jeruk nipis mungkin dipengaruhi adanya kandungan vitamin $\mathrm{B} 3, \mathrm{C}$, lutein dan zeaxantin yang 
terkandung dalam buah pare serta adanya kandungan vitamin $\mathrm{C}$ dan hesperidin dalam buah jeruk nipis. Kandungan vitamin B3 pada buah pare dapat menyebabkan peningkatan kadar kolesterol HDL yaitu dengan meningkatkan pengeluaran Apolipoprotein A-1 (Apo A-1) yang dapat mengakibatkan peningkatan kadar kolesterol HDL. Dimana, Apo A-1 merupakan protein utama penyusun HDL. ${ }^{14,29}$ Kandungan vitamin $\mathrm{C}$ dapat berfungsi melindungi kolesterol HDL dari oksidasi lipid..$^{39}$ Lutein dan zeaxanthin berdasarkan sebuah penelitian sebanyak 53\% ditemukan dan ditranspor dari hati ke jaringan melalui HDL. ${ }^{36,37}$ Lutein dan zeaxanthin sebagai antioksidan kuat dapat mengurangi lesi aterosklerosis pada hewan. Efek perlindungan dari HDL terhadap penyakit kardiovaskuler mungkin disebabkan sebagian besar kandungan antioksidannya berupa lutein dan zeaxanthin. ${ }^{38}$ Kandungan hesperidin pada jeruk nipis dapat membantu meningkatkan kadar kolesterol HDL, yaitu dengan meningkatkan pengeluaran Apo A-1. Selain itu hesperidin dalam buah jeruk bekerja untuk mempertahankan kembali vitamin $\mathrm{C}$ setelah digunakan untuk mengatasi radikal bebas. Dalam kata lain, hesperidin memperkuat efek dari vitamin C dalam tubuh. ${ }^{12,18,31}$ Senyawa dalam kombinasi jus pare dan jus jeruk nipis kemungkinan dapat menambah potensi zat-zat hipokolesterolemik yang terkandung pada buah pare dan jeruk nipis sehingga diperoleh efek hipokolesterolemik yang lebih optimal dan dapat meningkatkan kadar kolesterol HDL. Hal ini sesuai dengan sebuah penelitian yang menjelaskan bahwa asupan dari kombinasi buah-buahan dan sayuran (500 g) selama 4 minggu dihubungkan dengan peningkatan $64 \%$ konsentrasi vitamin C. Dianjurkan meminum sejumlah kombinasi berbagai jus untuk memperbaiki profil lipid darah, mengurangi stress oksidatif, mencegah aterogenik kolesterol LDL dan agregasi platelet serta meningkatkan kadar kolesterol HDL. ${ }^{19,25}$

\section{SIMPULAN}

Tidak ada perbedaan pengaruh pemberian jus pare, jus jeruk nipis dan kombinasi jus pare \& jus jeruk nipis terhadap peningkatan kadar kolesterol HDL.

\section{SARAN}

Pada penelitian selanjutnya perlu dilakukan uji kandungan vitamin $\mathrm{B} \& \mathrm{C}$, lutein dan zeaxanthin pada jus pare (Momordica charantia L.) dan hesperidin \& vitamin $\mathrm{C}$ pada jus jeruk nipis (Citrus aurantifolia).

\section{DAFTAR PUSTAKA}

1. Bayram F, Kocer D, Gundogan K, Kaya Ahmet, Demir Ozgur, Coskun Ramazan, et al. Prevalence of dyslipidemia and associated risk factors in Turkish adults. Journal of Clinical Lipidology 2014 (8); 206-16.

2. Cortes JMN, J. Pedro-Botet, Hernando AB, Rodriguez AD, P. Gonzalez-Santos, A. HernandezMijares, et al. Use of Expert Consensus to Improve Atherogenic Dyslipidemia Management. Rev Esp Cardiol 2014;67(1):36-44.

3. Riskesdas. Badan Penelitian dan Pengembangan Kesehatan Kementerian Kesehatan RI. 2013.

4. Grundy S, Arai H, Barter Philip, P. Bersot Thomas, John BD, Carmena R, et al. An International Atherosclerosis Society Position Paper: Global recommendations for the management of dyslipidemia Executive summary.Atherosclerosis 2014, 232; 410-13.

5. National Institutes of Health. Third Report of the National Cholesterol Education Program (NCEP) Expert Panel on Detection, Evaluation, and Treatment of High Blood Cholesterol in Adults (Adult Treatment Panel III). NIH Publication September 2002 No.02-5215.

6. Expert Dyslipidemia Panel of the International Atherosclerosis Society. An International Atherosclerosis Society Position Paper: Global recommendations for the management of dyslipidemia-Full report. Journal of Clinical Lipidology 2014, 8; 29-60.

7. Sharma U, Kishore J, PGDCHFWM, Garg A, Anand T, Chakraborty M, Lali P. Dyslipidemia and associated risk factors in a resettlement colony of Delhi. Journal of Clinical Lipidology 2013, 7; 65360.

8. Grover JK., Yadav SP. Pharmacological actions and potential uses of Momordica charantia: a review. Journal of Ethnopharmacology 2004, 93; 123-32.

9. Virdi J, Sivakami S, Shahani S, Suthar AC, Banavalikar MM., Biyani MK. Antihyperglycemic effects of three extracts from Momordica charantia. Journal of Ethnopharmacology 2003, 88; 107-11.

10. Fernandes NPC, Lagishetty CV, Panda VS and Naik SR. An experimental evaluation of the antidiabetic and antilipidemic properties of standardized Momordica charantia fruit extract. BMC Complementary and Alternative Medicine, 2007; 7:29.

11. Adimunca $C$, Nainggolan $O$. Efek buah pare (Momordica charantia L.) terhadap profil lipid serum tikus putih jantan strain Wistar derived LMR. J Cermin Dunia Kedokteran. 2009;36(2):97-100.

12. Suryawanshi JAS. An overview of Citrus aurantium used in treatment of various diseases. African Journal of Plant Science Vol. 5(7), 2011; pp. 390-95.

13. Fox JG, Cohen BJ, Loew FM. Laboratory animal medicine, $2^{\text {nd }}$ Edition. Academic Press Inc; 2002, 91-120. 
14. Shintawati R, Hernawati, Indraswati D. Kadar Lipid Darah Mencit Betina Middle-Aged Galur Swiss Webster setelah Pemberian Jus Buah Pare (Momordica charantia L.). MKB 2011, Volume 43 No. 2.

15. Matsui S, Yamane T, Takita T, Oishi Y, KobayashiHattor K. The hypocholesterolemic activity of Momordica charantia fruit is mediated by the altered cholesterol- and bile acid-regulating gene expression in rat liver. Nutrition Research 2013, 33 . hlm. 580-58.

16. Preising AN, Borges CT. Orange juice improved lipid profile and blood lactate of overweight middle-aged women subjected to aerobic training. Maturitas 2010, 67;343-47.

17. Borges CT, Preising AN, P. Araujo Milena, C. Vinagre Carmen, C. Maranhão Raul. Orange juice decreases low-density lipoprotein cholesterol in hypercholesterolemic subjects and improves lipid transfer to high-density lipoprotein in normal and hypercholesterolemic subjects. Nutrition Research 2010, 30; 689-94.

18. P Aptekmann Nancy and B Cesar Thais. Long-term orange juice consumption is associateted with low LDL-cholesterol and apolipoprotein B in normal and moderately hypercholesterolemic subjects. Lipids in Health and Disease 2013, 12:119, BioMed Central.

19. Ajugwo AO, Erhabor T, Adejumo B, Mokogwu T, Digban K, Ojieh G, Nnatuanya I. Nutritional Value of Lime and Lemon In Hypercholesterolaemic Induced Rats. Asian Journal of Medical Sciences 3 (2012) p.13-6.

20. Chen Z, Chu H, Chyau C, Chu C, Duh P. Protective effects of sweet orange (Citrus sinensis) peel and their bioactive compounds on oxidative stress. Food Chemistry 2012. 135 2119-127.

21. Kuntic V, Brboric J, Holclajtner-Antunovic I, Uskokovic-Markovic S. Evaluating the bioactive effects of flavonoid hesperidin - A new literature data survey. Vojnosanit Pregl 2014; 71(1): 60-5.

22. De Oliveira DM, Simoes Dourado GKZ and Cesar TB. Hesperidin associated with continuous and interval swimming improved biochemical and oxidative biomarkers in rats. Journal of the International Society of Sports Nutrition 2013, 10:27.

23. Olukanni OD, Akande OT, Alagbe Y.O, Adeyemi SO, Olukanni AT and Daramola GG. Lemon Juice Elevated Level of Reduced Glutathione and Improved Lipid Profile in Sprague Dawley Rats. American-Eurasian J. Agric. \& Environ. Sci., 2013. 13 (9): 1246-251.

24. Retnaningsih $\mathrm{CH}$, Sumardi, Atmira NU, Widowati W, Soeng S. Potensi Fraksi Aktif Kacang Koro (Mucuna pruriens. L) sebagai Penurun Kolesterol pada Tikus Hiperkolesterolemia. Media Farmasi Indonesia 2009, Vol.4 No.2.

25. Sánchez-Moreno C, Cano MP, Ancos B, Plaza L, Olmedilla B, Granado F, and Martín A. Effect of orange juice intake on vitamin $\mathrm{C}$ concentrations and biomarkers of antioxidant status in humans. Am J Clin Nutr 2003;78:454-60.

26. Boshtam M, Asgary S, Moshtaghian J, Naderi G, and Jafari-Dinani N. Impacts of fresh lime juice and peel on atherosclerosis progression in an animal model. ARYA Atheroscler 2013; volume 9, Issue: 357-62.

27. Edyanto PS. 2012. Perbedaan Kadar HDL (High Density Lipoprotein) pada Tikus Wistar (Rattus norvegicus) Jantan Setelah Terpapar Stresor Rasa Sakit Renjatan Listrik. Skripsi. Fakultas Kedokteran Gigi Universitas Jember.

28. I. Tsalissavrina, D. Wahono, D. Handayani. Pengaruh Pemberian Diet Tinggi Karbohidrat Dibandingkan Diet Tinggi Lemak Terhadap Kadar Trigliserida dan HDL darah. Jurnal Kedokteran Brawijaya; Agustus 2006, Vol. XXII, No.2.

29. Bhoomi K, Patel B, Parmar K. Efects of Momordica charantia Fruit on Cardiac Abnormalities Associated With Metabolic Syndrome. J adv Pharm Res Biosci. 2013; 1(1): 20-7.

30. D. Jamuna and R. Johanna. Antihyperlipidemic effect of ambrex, a polyherbal formulation against experimentally induced hypercholesterolemia in rats. Afr. J. Pharm. Pharmacol Vol. 7(25), pp. 1737 743, 8 July, 2013.

31. Demonty I, Lin Y, Zebregs YE, Vermeer MA, Van der Knaap H, Jakel M, and Trautwein EA. The Citrus Flavonoids Hesperidin and Naringin Do Not Affect Serum Cholesterol in Moderately Hypercholesterolemic Men and Women. The Journal of Nutrition; 2010.

32. Gropper SS, Smith JL, Groff JL. Advanced Nutrition and Human Metabolism. $5^{\text {th }}$ ed. Belmont: Wadsworth; 2009.p 115;74.

33. Balcombe, JP., Bernard, ND, et al. Laboratory Rountines Cause Animal Stress. American Association for Laboratory Animal Science; 2004: 43;6. p.47-8.

34. Mayes, PA. Sintesis, Pengangkutan, dan Ekskresi Kolesterol. Dalam: Murray RK, Ganner DK, Mayes PA, Rodwell VW, editor. Biokimia harper $25^{\text {th }}$ ed. Jakarta: EGC; 2003.

35. Solter et al. Elevated Serum Lipids in Veterans with Combat-related Chronic Posttraumatic Stress Disorder. Croat Med J 2002;43: p.685-89.

36. Sommerburg, Keunen, Bird, et al. Fruits and vegetables that are sources for lutein and zeaxanthin: the macular pigment in human eyes. $\mathrm{Br}$ J Ophthalmol 1998;82:907-10.

37. Connor et al. The Prime Role of HDL to Transport Lutein into the Retina: Evidence from HDLDeficient WHAM Chicks Having a Mutant ABCA1 Transporter. IOVS, September 2007, Vol. 48, No. 9.

38. Wang et al. Effect of dietary lutein and zeaxanthin on plasma carotenoids and their transport in lipoproteins in age-related macular degeneration. Am J Clin Nutr 2007;85:762-9. 
39. Hillstrom et al. Vitamin C Inhibits Lipid Oxidation in Human HDL. American Society for Nutritional Sciences. 2013;3047-51.

40. Riyanto S, Murwani H. 2011. Pengaruh Pemberian Yoghurt Kedelai Hitam (Black Soyghurt) terhadap Profil Lipid Serum Tikus Hiperkolesterolemia. Artikel Penelitian. Fakultas Kedokteran Universitas Diponegoro Semarang.

41. Murray, K., 2002, Harper Biochemestry, twenty fifth edition, Mc Graw Hill Companie, New York.

42. W Sri. Pemberian Minyak Ikan Lemuru (Sardinella longiceps) sebagai Anti Dislipidemia Melalui Peningkatan HDL Pada Tikus Wistar. JURNAL KIMIA 5 (2), JULI 2011 : 156-62.

43. E Prangdimurti, NS Palupi dan FR Zakaria. 2007. Metode Evaluasi Nilai Biologis Karbohidrat dan Lemak. Modul e-Learning ENBP, Departemen Ilmu \& Teknologi Pangan-Fateta-IPB.

44. Anwar TB. Penyakit Jantung Koroner Dan Hypertensi. Karya Tulis Ilmiah. Fakultas Kedokteran Universitas Sumatera Utara; 2004.

45. YS Tegar. 2012. Khasiat Minyak Zaitun (Olive Oil) Dalam Meningkatkan Kadar HDL (High Density Lipoprotein) Darah Tikus Wistar Jantan. Skripsi. Kedokteran Gigi Universitas Jember.

46. K. Rita, S. Mieke. Profil lipid pada penduduk lanjut usia di Jakarta. Universa Medicina, OktoberDesember 2005,Vol.24 No.4.

47. Tsalissavrina, Iva. 2006. Pengaruh Pemberian Diet Tinggi Karbohidrat dibandingkan Diet Tinggi Lemak terhadap Kadar Trigliserida dan HDL Darah pada Rattus novergicus Galur Wistar. Jurnal Kedokteran Brawijaya, Vol. XXII, No.2.

48. Ridwan A, Zakaria Z, Barlian A. Pengaruh Fotoperiode terhadap Respon Stres dan Parameter Reproduksi pada Mencit Jantan (Mus musculus L.) Galur Swiss Webster. Institut Tekhnologi Bandung. Jurnal Matematika \& Sains, April 2012, Vol. 17 Nomor 1.

49. Peterson JJ, Beecher GR, Bhagwat SA, Dwyer JT, Gebhardt SE, Haytowitz DB, Holde JM. Flavanones in grapefruit, lemons, and limes: A compilation and review of the data from the analytical literature. Journal of Food Composition and Analysis 19 (2006) S74-S80. 